\title{
ECONOMIC INDICATORS OF NITROGEN FERTILIZATION IN SUNFLOWER CULTIVARS
}

\author{
INDICADORES ECONÔMICOS DE ADUBAÇÃO NITROGENADA EM CULTIVARES \\ DE GIRASSOL
}

\begin{abstract}
Almir Rogerio Evangelista de SOUZA ${ }^{1}$; Ênio Gomes Flôr SOUZA ${ }^{1}$; Francilene de Lima TARTAGLIA ${ }^{1}$; Allysson Pereira dos SANTOS ${ }^{1}$; Aurélio Paes BARROS JÚNIOR ${ }^{2 *}$; Lindomar Maria da SILVEIRA ${ }^{2}$; Francisco BEZERRA NETO ${ }^{2}$; Manoel Galdino dos SANTOS ${ }^{2}$
\end{abstract}

1. Instituto Federal de Educação, Ciência e Tecnologia de Alagoas, Campus Piranhas, Piranhas, AL, Brasil; 2. Universidade Federal Rural do Semi-Árido, Centro de Ciências Agrárias, Departamento de Ciências Agronômicas e Florestais, Programa de Pós-Graduação em Fitotecnia, Mossoró, RN, Brasil. *aurelio.barros@ufersa.edu.br

\begin{abstract}
Sunflower is one of the most important oilseeds in the world. However, cultivation in semi-arid regions requires analysis of production costs and profitability, ensuring effective decision-making, focused on farming procedures and techniques. In two agricultural crops, 2016 and 2017, experiments were conducted to evaluate the economic indicators of sunflower cultivars ('Aguará 06', 'Altis 99', 'Multissol' and 'BRS 122') submitted to nitrogen $(\mathrm{N})$ doses $\left(0 ; 30 ; 60 ; 90\right.$ and $\left.120 \mathrm{~kg} \mathrm{ha}^{-1}\right)$ via fertirrigation under semi-arid conditions. The net margin corresponded to the increase of $\mathrm{N}$ doses, reaching a maximum net margin in the 2016 harvest of R $\$ 366.89 \mathrm{ha}^{-1}$ at the dose of $81 \mathrm{~kg} \mathrm{ha}^{-1}$ of $\mathrm{N}$ for 'BRS 122'; R $\$ 577.41 \mathrm{ha}^{-1}$ with $118 \mathrm{~kg} \mathrm{ha}^{-1}$ of $\mathrm{N}$ for 'Multissol'; and for 'Aguará 06' (R\$ 2,124.00 ha $\mathrm{ha}^{-1}$ ) and 'Altis 99' (R\$ $\left.976.66 \mathrm{ha}^{-1}\right)$ at the dose of $120 \mathrm{~kg}$ $\mathrm{ha}^{-1}$ of N. In the 2017 harvest, 'BRS 122' obtained R\$190.90 ha ${ }^{-1}$ in the dose of $83 \mathrm{~kg} \mathrm{ha}^{-1}$ of N and 'Multissol' reached $\mathrm{R} \$ 657.50$ in the dose of $85 \mathrm{~kg} \mathrm{ha}^{-1}$ of $\mathrm{N}$; the cultivars 'Aguará 06' (R\$ 1,078.00 ha $\mathrm{ha}^{-1}$ ) and 'Altis 99' $\left(\mathrm{R} \$ 957.14 \mathrm{ha}^{-1}\right)$ in the dose of $120 \mathrm{~kg} \mathrm{ha}^{-1}$ of $\mathrm{N}$. The rate of return and the profitability index were positive for all cultivars in both crops.
\end{abstract}

KEYWORDS: Helianthus annuus. Production cost. Productivity. Planting season.

\section{INTRODUCTION}

The sunflower (Helianthus annuus L.) is one of the main oilseeds in the world economic scenario, since it favors a wide variety of use and mainly for the production of high quality oil (CASTRO; LEITE, 2018). Occupying a growing area on all continents, with around 26.2 million hectares (FAO, 2018), sunflower cultivation represents great potential in the supply of raw material for the production of biofuels, since it contributes about of $13 \%$ of all vegetable oil produced in the world (USDA, 2018).

Brazil is gradually expanding its production areas, aiming to reduce imports of achenes, oil, meal and other by-products of sunflower, considering that the current areas of cultivation are incipient to supply growing domestic demand, represented by $0.5 \%$ of the area in terms of world production (USDA, 2018).

In addition, the results of the research carried out in the country show the existence of an important potential, which guarantees the development of sunflower production in different seasons and localities during the agricultural year (CAPONE et al., 2012; SIMÕ̃ES et al., 2018). This characteristic makes possible the cultivation at different times of the main crops already consolidated, not requiring the substitution, but rather complementing the use of land, of machines, equipment, processing industry, means of transport and storage (PERSON, 2016).

As for profitability, sunflower cultivation has shown important results in several cultivation regions (SILVA, 2009; TARSINATO et al., 2016). In the Brazilian Northeast, the sunflower in succession to other crops, is shown as an important alternative for the farmer, as it aims to reduce the idleness of irrigated areas, to cover fixed operational costs of the main crop, optimizing land use, irrigation system and manpower, besides making it possible to obtain net margin with the production of achenes and oil in the off season.

However, unlike the main sunflower producing regions in Brazil, where cultivation is rarely irrigated, cultivation in the Brazilian Northeast region, and especially in semi-arid conditions, requires the use of irrigation systems, 
which have been frequently associated with the use of nutrients through the fertirrigation technique, mainly with the use of soluble fertilizers, among them nitrogenous fertilizers (SINCIK; GOKSOY; DOGAN, 2013).

Nitrogen $(\mathrm{N})$ is the main element for sunflower growth and yield (KIANI et al., 2016). Several studies have emphasized the effect of different doses of $\mathrm{N}$ on the total biomass of sunflower and its relation in protein and oil biosynthesis (SINCIK; GOKSOY; DOGAN, 2013; WABEKWA; DEGRI; DANGARI, 2012). However, when there is no adequate management, $\mathrm{N}$ fertilization is considered one of the factors that most onerous for the production costs (KANTER; ZHANG; MAUZERALL, 2015; MATSON; NAYLOR; ORTIZ, 1998).

Thus, it should be mentioned that the determination of production costs constitutes an instrument of significant importance in agriculture, not only as capable of offering elements necessary for the analysis of profitability of the production unit, but also as a parameter of decision-making and capitalization of the rural sector.

In this sense, the objective of the work was to determine the economic indicators of sunflower cultivars fertirrigated with $\mathrm{N}$ doses in two agricultural crops, in semi-arid conditions.

\section{MATERIAL AND METHODS}

The experiments were carried out in the field of Experimental Farm Rafael Fernandes $\left(5^{\circ} 03^{\prime} \mathrm{S}, 37^{\circ} 23^{\prime} \mathrm{W}, 18 \mathrm{~m}\right.$ high) in the 2016 and 2017 crops (February to May), belonging to the Federal Rural Semi-Arid University (UFERSA), located in the municipality of Mossoró-RN. The climatic classification, according to Köppen, is BShw', tropical semi-arid, very hot and dry, predominating two climatic seasons: a rainy season, usually from February to May and a drought from June to January, with a mean temperature of $27.4{ }^{\circ} \mathrm{C}$ and rainfall with a mean of $673.9 \mathrm{~mm}$ (SOBRINHO et al., 2011). The average meteorological data of the period of the experiments are presented in Table 1.

Table 1. Cumulative rainfall $(\mathrm{mm})$ and monthly average values of average air temperature $\left({ }^{\circ} \mathrm{C}\right)$, air relative humidity (\%), global solar radiation $\left(\mathrm{MJ} \mathrm{m}^{-2}\right.$ day $\left.^{-1}\right)$ corresponding to the months from February to May of the agricultural crops 2016 and 2017, in semi-arid conditions.

\begin{tabular}{llccc}
\hline Agricultural crops & $\begin{array}{c}\text { Rainfall } \\
(\mathrm{mm})\end{array}$ & $\begin{array}{c}\text { Average air } \\
\text { temperature } \\
\left({ }^{\circ} \mathrm{C}\right)\end{array}$ & $\begin{array}{c}\text { Air relative } \\
\text { humidity } \\
(\%)\end{array}$ & $\begin{array}{c}\text { Global solar } \\
\text { radiation } \\
\left(\mathrm{MJ} \mathrm{m}^{-2} \mathrm{dia}^{-1}\right)\end{array}$ \\
\hline February $/ 2016$ & 0.4 & 28.6 & 72.4 & 21.9 \\
March $/ 2016$ & 3.2 & 29.1 & 68.8 & 23.5 \\
April /2016 & 68.6 & 28.2 & 75.1 & 19.1 \\
May /2016 & 0.8 & 28.4 & 67.6 & 21.2 \\
\hline Mean & $73.0^{*}$ & 28.5 & 70.9 & 21.4 \\
\hline February /2017 & 3.6 & 28.2 & 69.5 & 19.0 \\
March /2017 & 76.0 & 27.5 & 76.2 & 19.3 \\
April /2017 & 67.0 & 27.4 & 76.9 & 19.8 \\
May /2017 & 41.8 & 27.8 & 72.0 & 23.4 \\
\hline Averages & $188.4^{*}$ & 27.7 & 73.6 & 20.3 \\
\hline
\end{tabular}

*Cumulative rainfall.

The soil was classified as Dystrophic Yellow Red Latosol, sand franc textural class (EMBRAPA, 2013). With the following physical characteristics: coarse sand $=660 \mathrm{~g} \mathrm{~kg}^{-1}$; fine sand $=$
$220 \mathrm{~g} \mathrm{~kg}^{-1} ;$ silt $=20 \mathrm{~g} \mathrm{~kg}^{-1}$; clay $=100 \mathrm{~g} \mathrm{~kg}^{-1}$; and the chemicals, after liming (SILVA, 2009), are described in Table 2.

Table 2. Soil chemical analyzes of the experimental area after liming and before sowing of the sunflower cultivars in two agricultural crops (2016 and 2017), in semi-arid conditions.

\begin{tabular}{|c|c|c|c|c|c|c|c|c|}
\hline & $\mathrm{pH}$ & $\mathrm{OM}^{*}$ & $\mathrm{~N}$ & $\mathrm{P}$ & $\mathrm{K}^{+}$ & $\mathrm{Ca}^{2+}$ & $\mathrm{Mg}^{2+}$ & $\mathrm{Al}^{3+}$ \\
\hline Crops & $\mathrm{H}_{2} \mathrm{O}$ & $\mathrm{g} \mathrm{kg}^{-1}$ & $\mathrm{~g} \mathrm{~kg}^{-1}$ & - & $-m g d n$ & --- & \multicolumn{2}{|c|}{$-\mathrm{cmol}_{\mathrm{c}} \mathrm{dm}^{-3}-$} \\
\hline 2016 & 5.90 & 7.52 & 0.42 & 2.21 & 27.10 & 0.40 & 0.57 & 0.00 \\
\hline 2017 & 5.80 & 4.38 & 0.32 & 1.90 & 32.40 & 1.40 & 0.70 & 0.00 \\
\hline
\end{tabular}


The experimental design was in randomized blocks, in subdivided plots, with four replications. In the plots, $\mathrm{N}$ doses $\left(0 ; 30 ; 60 ; 90\right.$ and $120 \mathrm{~kg} \mathrm{ha}^{-1}$ of $N$ ) were evaluated, and in the subplots the four sunflower cultivars 'Aguará 06', 'Altis 99', 'Multissol' and 'BRS 122'. The plots consisted of four plant lines, with spacing of $0.7 \mathrm{~m}$ between rows and $0.3 \mathrm{~m}$ between plants, totaling an area of 12.6 $\mathrm{m}^{2}$. As harvest area, the two central lines were considered, discarding a plant at each end of the lines.

The soil preparation consisted of plowing, liming and harrowing. After 45 days, foundation fertilization was carried out on the basis of soil analysis and recommendations for the use of correctives and fertilizers in Minas Gerais (RIBEIRO; GUIMARÃES; VENEGAS, 1999). The source of $\mathrm{N}$ used was urea ( $45 \%$ of $\mathrm{N})$, supplied via irrigation water, using a shunt tank produced with polyvinyl polychloride pipe (TAVARES, 2015).

The doses of $\mathrm{N}$ were divided into three equal applications, one third of the dose at sowing and the other applied at the reproductive stages R1 (visible inflorescence) and R3 (floral bud at a distance greater than $2 \mathrm{~cm}$ from the last leaf). Potassium was applied at a dose of $70 \mathrm{~kg} \mathrm{ha}^{-1} \mathrm{~K}_{2} \mathrm{O}$ $\left(60 \% \quad \mathrm{~K}_{2} \mathrm{O}\right)$ as potassium chloride $(\mathrm{KCl})$, fertirrigated in three equal applications along with the N.

Seeding was done manually on $02 / 23 / 2016$ (first harvest) and 02/24/2017 (second harvest), at a depth of four centimeters, using three seeds per hole. The thinning was performed ten days after sowing leaving one plant per hole.

Manual harvesting was carried out in the final phase of phenological maturation (R9), when the bracts, the back of the chapter and the stem were brown to dark brown. This phase corresponded to 88 days after sowing (DAS) for cultivars 'BRS 122' and 'Multissol' and 95 DAS for 'Altis 99' and 'Aguará 06' cultivars in the 2016 harvest. In 2017, for 'BRS 122' and 'Multissol' was at 90 DAS, and for 'Altis 99' and 'Aguará 06' at 98 DAS. The trail and cleaning of the achenes were done manually. Productivity was calculated when the humidity of the achenes was on average $13 \%$.

The economic indicators were used with the purpose of evaluating the treatments. The costs of producing one hectare of sunflower under $\mathrm{N}$ doses via fertirrigation were estimated in two agricultural crops, calculated and analyzed at the end of each production process, adapting the methodology proposed by (TAVARES, 2015).

Variable costs for the cultivation of sunflowers included expenditure on crop costs (labor, seeds, fertilizers, agrochemicals and others), administrative expenses, technical assistance, rural territorial tax (RTT), financial expenses (financing interest); fixed costs - depreciation and periodic maintenance of improvements/installations; and income from factors - expected remuneration on fixed capital and lease.

Administrative expenses and technical assistance corresponded respectively to the percentages of 3 and $2 \%$ of the total cost of the crop. It was considered the minimum to be paid RTT in one agricultural year ( $\mathrm{R} \$ 10.00)$, using Equation 1:

BTT $\left(\mathrm{R} \$ \mathrm{ha}^{-1}\right)=\mathrm{RTT}$ value $(\mathrm{R} \$)^{*}$ : $\left(\frac{\text { Cycle of culture (days) }}{365 \text { days }}\right)$

Interest from the financing came from the resources needed to finance the crop, with interest rates according to the time of release or use of capital (rate of $7.49 \%$ year $^{-1}$ ), calculated according to Equation 2.

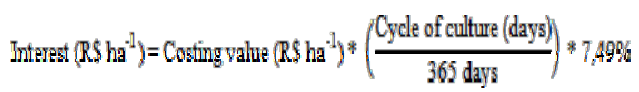

The calculation for the depreciation of improvements/facilities was obtained through the design of irrigation system for one hectare of sunflower, according to the density of plants, requiring 14,300 meters of low density polyethylene drip tapes with emitters spaced $0.30 \mathrm{~m}$ and nominal diameter of $16 \mathrm{~mm}$ (value $=\mathrm{R} \$ 0.24 \mathrm{~m}^{-1}$ ), in addition to PVC pipes and fittings (value $=\mathrm{R} \$$ 2,986.50 ha ${ }^{-1}$ ). According to Cunha et al. (2012), the approximate life of the drip tape is two years and the sixteen-year pipes and fittings in semi-arid conditions. In this way, the system depreciation was calculated according to Equation 3.

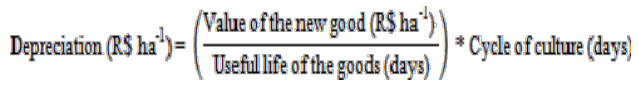

Maintaining the irrigation system and facilities becomes an essential and gradual process for longer life and efficiency of use. For the calculation of maintenance with a defined rate of $1 \%,(\mathrm{CONAB}, 2010)$ established the employment of Equation 4.

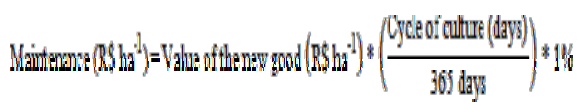

Data from Conab (2010) emphasize that producer investment must be remunerated and uses the percentage of $6 \%$ per year for the rate of return, 
similar to the capital invested in other optional forms (Equation 5).

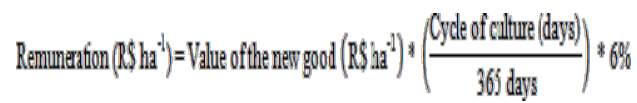

For rental of land, which is one of the factors of production, the lease per hectare established in the West region Potiguar-RN (R\$ 1,200.00 ha $^{-1}$ year $^{-1}$ ), Equation 6 was considered for calculation purposes.

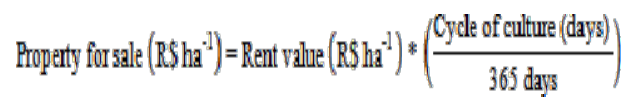

Gross income (GI) was measured by the amount paid per kilogram of achenes in the municipality of Mossoró-RN (R\$2.00 kg $\mathrm{kg}^{-1}$, in both crops). GI was equivalent to the value of $\mathrm{kg}$ of achenes by the productivity per hectare. The quotation of US\$ 1.00 corresponded to R $\$ 3.59$ in the 2016 crop and of $R \$ 3.23$ in 2017.

The net income (NI) was calculated by the difference between the gross income (GI) and the total costs (TC) of the production of achenes. The rate of return (RR) was determined from the relation between GI (production value) and TC, corresponding to the capital obtained for each real (R\$) applied to sunflower cultivation in semi-arid conditions. The profitability index (PI) consisted of the relation between NI and GI, expressed as a percentage.

The data were submitted to analysis of variance in each agricultural crop (2016 and 2017), through the program Sisvar, version 5.6 (FERREIRA, 2011). Subsequently, joint analysis was performed for the characteristics with homogeneity of variances between the harvests (PIMENTEL GOMES, 2009). Regression analyzes were performed using the Table Curve 2D application, version 5.01 (JANDEL SCIENTIFIC, 1992).

\section{RESULTS AND DISCUSSION}

According to the data analysis for productivity and economic evaluation for the production of sunflower achenes (Table 3), interactions were obtained between agricultural crops, $\mathrm{N}$ doses and cultivars for the productivity characteristics of achenes, gross income, net income, rate of return, and profitability index.

Table 3. F values for the joint analysis of variance for the variables yield of achenes (YA), gross income (GI), net income $(\mathrm{NI})$, rate of return (RR) and profitability index (PI) in the production of sunflower cultivars fertirrigated with nitrogen doses in two agricultural crops in the city of Mossoró, semi-arid Brazilian.

\begin{tabular}{|c|c|c|c|c|c|c|}
\hline \multirow[b]{2}{*}{ Sources of variation } & \multicolumn{6}{|c|}{ F values } \\
\hline & DF & YA & GI & $\mathrm{NI}$ & RR & PI \\
\hline Blocks (Crops) & 6 & $3.60^{n s}$ & $3.29^{n s}$ & $3.28^{n s}$ & $2.17^{n s}$ & $0.73^{n s}$ \\
\hline Crops & 1 & $2.36^{n s}$ & $1.97^{n s}$ & $12.84 *$ & $26.62 * *$ & $167.02 *$ \\
\hline Doses & 4 & $53.00 * *$ & $51.84 * *$ & $36.42 * *$ & $51.39 * *$ & $342.42 *$ \\
\hline Doses*Crops & 4 & $3.50 *$ & $3.25 *$ & $3.10^{*}$ & $4.95 * *$ & $56.01 *$ \\
\hline Cultivars & 3 & $16.07 * *$ & $15.80 * *$ & $15.82 * *$ & $18.67 * *$ & $83.25^{*}$ \\
\hline Cultivars*Crops & 3 & $1.15^{n s}$ & $0.97^{n s}$ & $0.97^{n s}$ & $1.56^{n s}$ & $1.16^{n s}$ \\
\hline Cultivar*Dose & 12 & $1.92 *$ & $1.87 *$ & $1.87 *$ & $2.46 * *$ & $20.16^{*}$ \\
\hline Crops*Doses*Cultivars & 12 & $2.78 * *$ & $2.81 * *$ & $2.81 *$ & $3.13 * *$ & $9.96 * *$ \\
\hline CV $1(\%)$ & & 23.72 & 24.30 & 12.5 & 20.09 & 23.6 \\
\hline CV $2(\%)$ & & 23.17 & 23.14 & 11.9 & 20.22 & 22.4 \\
\hline Overall mean & & $1,115.43$ & $2,226.75$ & 430.96 & 1.23 & 44.45 \\
\hline
\end{tabular}

${ }^{\mathrm{ns}}$ : not significant at $5 \%$ probability, by the $\mathrm{F}$ test; **: significant at $1 \%$ probability, by the $\mathrm{F}$ and $*$ test: significant at $5 \%$ probability, by the F test; DF: degrees of freedom; CV: coefficient of variation.

In 2016 , the $\mathrm{N}$ doses of 81.8 and $86.6 \mathrm{~kg}^{-} \mathrm{ha}^{-}$ ${ }^{1}$ corresponded to the maximum yield of achenes for 'Multissol' cultivars (1,331.00) and 'BRS 122' $(1,424.00) \mathrm{kg} \mathrm{ha}^{-1}$ (Figure 1A). From this maximum value of $\mathrm{N}$ it was observed a reduction in the productivity of these cultivars. For 'Aguará 06 ' and
'Altis 99 ' the productivity of 2,087.41 and 1,504.20 $\mathrm{kg} \mathrm{ha}{ }^{-1}$ of achenes was reached with the fertirrigation of $120 \mathrm{~kg} \mathrm{ha}^{-1}$ of $\mathrm{N}$, corresponding to the increase of 13.39 and $7.83 \mathrm{~kg}$ of achenes per $\mathrm{kg}$ of fertirrigated $\mathrm{N}$ (Figure 1A). 

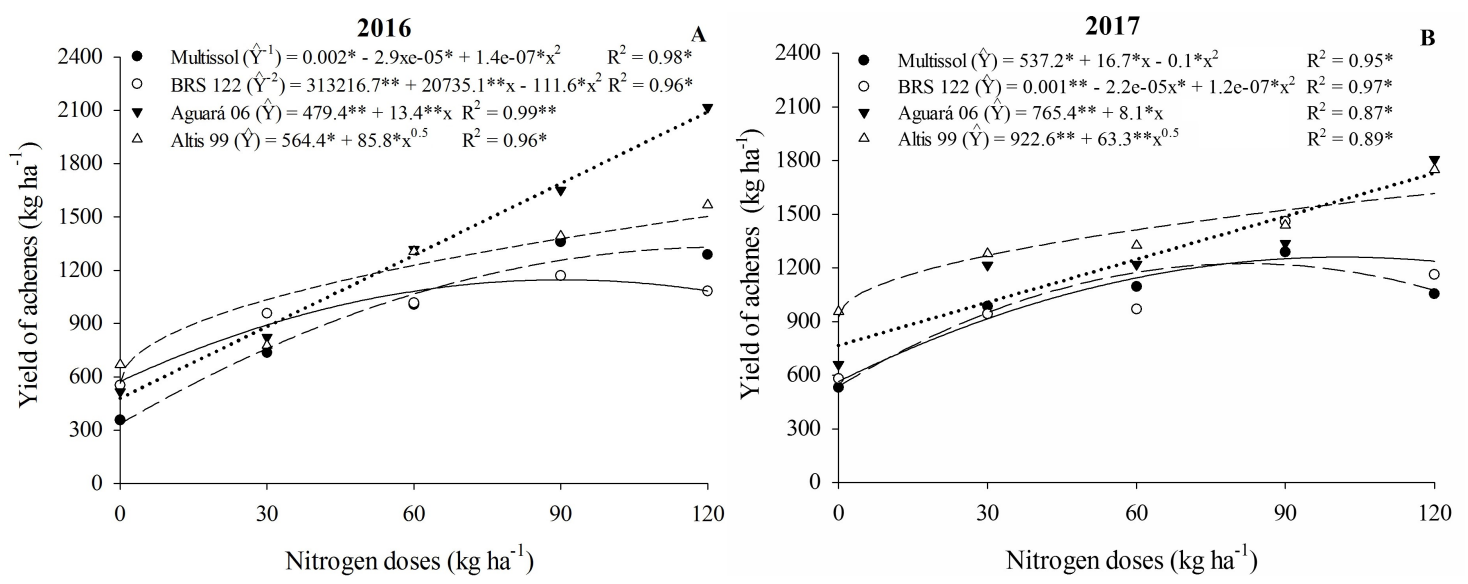

Figure 1. Yield of achenes of sunflower cultivars as a function of nitrogen doses, agricultural crop 2016 (A) and 2017 (B) in the Brazilian semi-arid.

In the 2017 harvest, the $\mathrm{N}$ doses required for the maximum production of sunflower achenes was 100.7 and $92.8 \mathrm{~kg} \mathrm{ha}^{-1}$ for 'Multisol' $(1,385.90 \mathrm{~kg}$ $\left.\mathrm{ha}^{-1}\right)$ and 'BRS 122' $\left(1,128.00 \mathrm{~kg} \mathrm{ha}^{-1}\right)$, respectively (Figure 1B). For 'Aguará 06' and 'Altis 99', the productivity of achenes increased linearly up to the dose of $120 \mathrm{~kg} \mathrm{ha}^{-1}$ of $\mathrm{N}$, with maximum values of 1,737.4 and 1,616.1 $\mathrm{kg} \mathrm{ha}^{-1}$, respectively (Figure 1B).

This productive response can be attributed to the genetic effect of each cultivar, since the nutritional requirement and the productivity can be variable among cultivars of the same species, being common to observe differentiated productivity under the same conditions of $\mathrm{N}$ fertilization, for the same agricultural crop (SANTOS et al., 2002; SHWERS et al., 2016).

Guedes Filho et al. (2011) obtained similar results with the dose of $100 \mathrm{~kg} \mathrm{ha}^{-1}$ of $\mathrm{N}$ for the cultivar Embrapa $122 / \mathrm{V} 2000$ in semi-arid conditions of the Northeast. Similarly, (SCHWERZ et al., 2016) reported maximum productivity at the dose of $132 \mathrm{~kg} \mathrm{ha}^{-1}$, obtaining $2,495.00 \mathrm{~kg} \mathrm{ha}^{-1}$ of achenes. Using the dose of $150 \mathrm{~kg} \mathrm{ha}^{-1}$ of $\mathrm{N}$ obtained productivity of $2,409.00 \mathrm{~kg} \mathrm{ha}^{-1}$ of achenes (ARSHAD et al., 2016).
In the two agricultural crops, the value paid per kilo of achenes did not vary $\left(\mathrm{R} \$ 2.00 \mathrm{~kg}^{-1}\right)$, whose gross income was proportional to the productivity obtained by the cultivar in the crops (Figure 2A), that is, at the dose of $81.8 \mathrm{~kg} \mathrm{ha}^{-1}$ of $\mathrm{N}$, the 'Multissol' cultivar reached a maximum gross income of R\$ 2,662.00 ha-1, while 'Aguará 06' and 'Altis 99' at the dose of $120 \mathrm{~kg} \mathrm{ha}^{-1}$ of $\mathrm{N}$ were R\$ $4,175.40 \mathrm{ha}^{-1}$ and R $\$ 3,144.31 \mathrm{ha}^{-1}$, respectively. For 'BRS 122', average gross income was R\$ 1,923.00 $\mathrm{ha}^{-1}$, results obtained in the 2016 harvest (Figure 2A).

In the 2017 harvest, 'Aguará 06' and 'Altis 99' cultivars reached maximum gross incomes of R\$ 3,396.08 ha $\mathrm{h}^{-1}$ and R $\$ 2,850.75 \mathrm{ha}^{-1}$, at a dose of 120 $\mathrm{kg} \mathrm{ha}^{-1}$ of $\mathrm{N}$, respectively, the 'BRS 122' of R\$ $2,584.54 \mathrm{ha}^{-1}$ at the dose of $92.1 \mathrm{~kg} \mathrm{ha}^{-1}$ of N (Figure 2B). The 'Multissol' cultivar average income was of R\$ $1,941.35 \mathrm{ha}^{-1}$. The gross income in the agricultural crops was similar, considering the productivities obtained and the stable price paid per kilo of achenes. Such increments were similar to those found by (BANERJEE et al., 2014; KHAKWANI et al., 2014; SCHULTZ et al., 2018). 

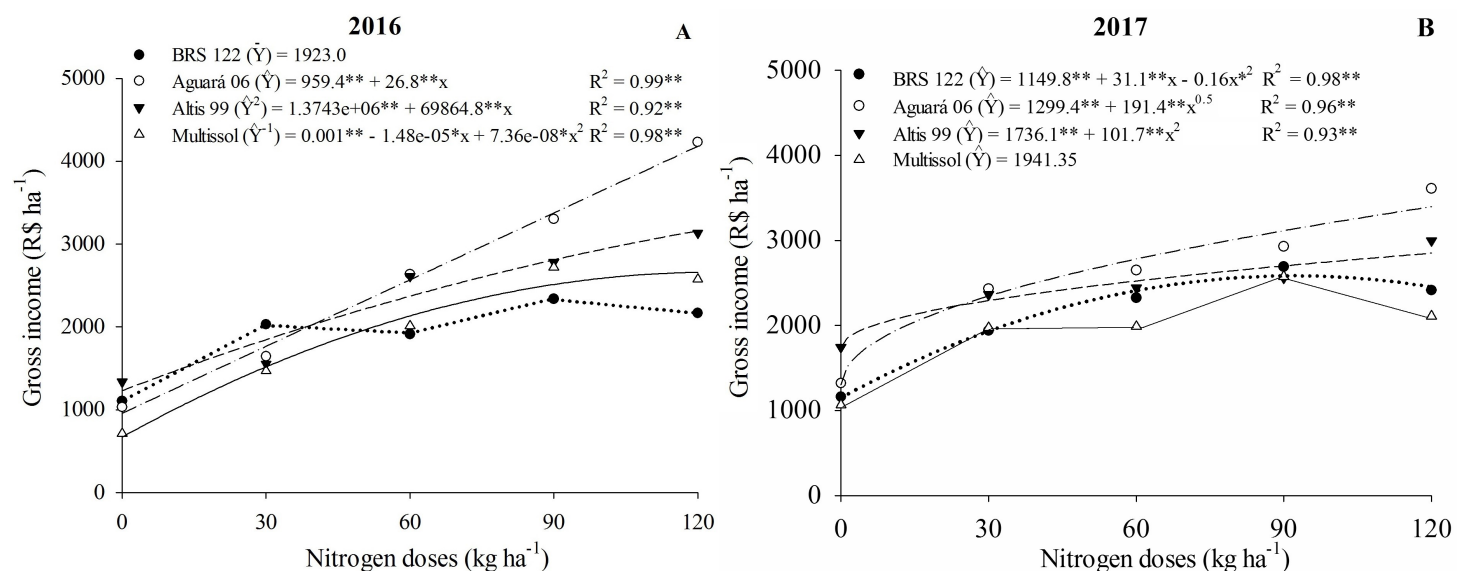

Figure 2. Gross income of sunflower cultivars fertirrigated with nitrogen doses in the 2016 (A) and 2017 (B) crops in the Brazilian semi-arid.

Table 4 shows the technical coefficients and the prices used in the production costs of one hectare of sunflower fertirrigated with $\mathrm{N}$ doses in two agricultural crops. The total costs in the agricultural crops were variable among the cultivars, due to the seed prices and the $\mathrm{N}$ doses in the agricultural crops.

The estimated costs in relation to $\mathrm{N}$ doses used in 2016 were (Table 4): R\$ 1,521.84 ha (absence of $\mathrm{N}$ fertilization); R\$ $1,590.15 \mathrm{ha}^{-1}(30 \mathrm{~kg}$ ha $^{-1}$ of N); R \$ 1,658.47 ha ${ }^{-1}\left(60 \mathrm{~kg} \mathrm{ha}^{-1}\right.$ of N); R\$ $1,726.39 \mathrm{ha}^{-1}\left(90 \mathrm{~kg} \mathrm{ha}^{-1} \mathrm{~N}\right)$ and $\mathrm{R} \$ 1,796.75 \mathrm{ha}^{-1}$ $\left(120 \mathrm{~kg} \mathrm{ha}^{-1} \mathrm{~N}\right)$. In the 2017 harvest, in turn, were (Table 4): R $\$ 1,638.55 \mathrm{ha}^{-1}$ (absence of nitrogen fertilization); R $\$ 1,758.83 \mathrm{ha}^{-1}\left(30 \mathrm{~kg} \mathrm{ha}^{-1}\right.$ of N); R\$ $1,834.12 \mathrm{ha}^{-1}\left(60 \mathrm{~kg} \mathrm{ha}^{-1} \mathrm{~N}\right) ; \mathrm{R} \$ 1,909.41 \mathrm{ha}^{-1}(90 \mathrm{~kg}$ $\left.\mathrm{ha}^{-1} \mathrm{~N}\right)$ and $\mathrm{R} \$ 1,989.31 \mathrm{ha}^{-1}\left(120 \mathrm{~kg} \mathrm{ha}^{-1} \mathrm{~N}\right)$.

In terms of costs, nitrogen fertilization corresponded to $4.10 \%\left(30 \mathrm{~kg} \mathrm{ha}^{-1}\right) ; 7.90 \%(60 \mathrm{~kg}$ $\left.\mathrm{ha}^{-1}\right) ; 11.30 \%\left(90 \mathrm{~kg} \mathrm{ha}^{-1}\right)$ and $14.40 \%\left(120 \mathrm{~kg} \mathrm{ha}^{-1}\right)$ in 2016 and $4.20 \%\left(30 \mathrm{~kg} \mathrm{ha}^{-1}\right), 8.10 \%\left(60 \mathrm{~kg} \mathrm{ha}^{-1}\right)$, $11.60 \%\left(90 \mathrm{~kg} \mathrm{ha}^{-1}\right)$ and $14.80 \%\left(120 \mathrm{~kg} \mathrm{ha}^{-1}\right)$ in the 2017 harvest (Table 4).

Table 4. Total costs in the production of one hectare of sunflower fertirrigated with doses of nitrogen $(\mathrm{N})$ in two agricultural crops in the Brazilian semi-arid.

\begin{tabular}{lcrrrr}
\hline \multicolumn{1}{c}{ Discrimination } & \multicolumn{2}{c}{ Crop 2016 } & \multicolumn{2}{c}{ Crop 2017 } \\
\hline I- Cost expenditure on the crops & Unity & Amount & $\mathrm{R} \$$ & Amount & $\mathrm{R} \$$ \\
\hline 1- Machine rental & & & & & \\
Tractor with disk harrow & $\mathrm{h}$ & 1.50 & 165.00 & 1.50 & 165.00 \\
2- Labor & & & & & \\
Distribution of drip tapes & daily & 2.00 & 80.00 & 2.00 & 100.00 \\
Manual planting & daily & 1.00 & 40.00 & 1.00 & 50.00 \\
Irrigation or fertigation & $\mathrm{h}$ & 74.80 & 127.16 & 52.70 & 89.59 \\
Weeding and spraying & daily & 1.00 & 40.00 & 2.00 & 100.00 \\
Manual harvesting of chapters & daily & 1.00 & 40.00 & 1.00 & 50.00 \\
Track and manual cleaning & daily & 3.00 & 120.00 & 3.00 & 150.00 \\
3- Seeds & & & & & \\
'Multissol' & $\mathrm{kg}$ & 4.00 & 52.00 & 4.00 & 60.00 \\
'Aguará 06' & $\mathrm{kg}$ & 4.00 & 48.00 & 4.00 & 56.00 \\
'Altis 99' & $\mathrm{kg}$ & 4.00 & 40.00 & 4.00 & 50.80 \\
'BRS 122' & $\mathrm{kg}$ & 4.00 & 32.00 & 4.00 & 40.00 \\
4- Fertilizers & & & & & \\
Limestone & $\mathrm{kg}$ & 950.00 & 180.50 & 950.00 & 180.50 \\
Urea (45\% N) - 120 kg ha ${ }^{-1}$ of N & $\mathrm{kg}$ & 266.60 & 261.27 & 266.60 & 287.93
\end{tabular}




\begin{tabular}{|c|c|c|c|c|}
\hline Potassium chloride $\left(70 \mathrm{~kg} \mathrm{ha}^{-1}\right.$ de $\left.\mathrm{K}_{2} \mathrm{O}\right)$ & 116.60 & 118.93 & 116.60 & 137.59 \\
\hline Borax $\left(1 \mathrm{~kg} \mathrm{ha}^{-1} \mathrm{de} \mathrm{B}\right)$ & 1 & 24.00 & 1 & 27.70 \\
\hline \multicolumn{5}{|l|}{5 - Pesticides } \\
\hline Thiametoxam $\left(10 \mathrm{~g} \mathrm{~kg}^{-1}\right)$ & 0.20 & 6.70 & 0.20 & 6.70 \\
\hline \multicolumn{5}{|l|}{6 - Others } \\
\hline Soil analysis & 1.00 & 35.00 & 1.00 & 35.00 \\
\hline Subtotal (A) & & $1,238.56$ & & $1,380.01$ \\
\hline \multicolumn{5}{|l|}{ II - Other expenses } \\
\hline 7 - Administrative expenses ( $3 \%$ of the cost of the crop) & & 37.16 & & 41.69 \\
\hline $8-$ Technical assistance ( $2 \%$ of the cost of the crop) & & 24.77 & & 27.79 \\
\hline 9 - Rural territorial tax $\left(\mathrm{R} \$ 10.00\right.$ year $\left.^{-1}\right)$ & & 2.47 & & 2.68 \\
\hline Subtotal (B) & & 64.40 & & 72.16 \\
\hline \multicolumn{5}{|l|}{ III - Financial expenses } \\
\hline 10 - Interest on financing ( $7.49 \%$ year-on-year) & & 22.87 & & 27.94 \\
\hline Subtotal (C) & & 22.87 & & 27.94 \\
\hline Variable cost $(\mathrm{A}+\mathrm{B}+\mathrm{C}=\mathrm{D})$ & & $1,325.83$ & & $1,480.11$ \\
\hline $\begin{array}{l}\text { IV - Fixed costs } \\
12 \text { - Maintenance of facilities }\left(1 \% \text { year }^{-1}\right)\end{array}$ & & 18.20 & & 19.81 \\
\hline Subtotal (E) & & 18.20 & & 19.81 \\
\hline Operational cost $(\mathrm{D}+\mathrm{E}=\mathrm{F})$ & & $1,344.03$ & & $1,499.92$ \\
\hline $\begin{array}{l}\text { V - Income from factors } \\
13 \text { - Remuneration on fixed capital }\left(6 \% \text { year }^{-1}\right) \\
14-\text { Rental }\left(\mathrm{R} \$ 1,300.00 \mathrm{ha}^{-1} \text { year }^{-1}\right)\end{array}$ & & $\begin{array}{l}102.29 \\
337.50 \\
\end{array}$ & & $\begin{array}{l}100.18 \\
379.70 \\
\end{array}$ \\
\hline Subtotal (G) & & 439.79 & & 479.88 \\
\hline Total cost $(\mathrm{H}+\mathrm{I}=\mathrm{J}) * *$ & & Crop /16 & & Crop $/ 17$ \\
\hline $120 \mathrm{~kg} \mathrm{ha}^{-1}$ de $\mathrm{N}$ & & $1,796.76$ & & $1,979.80$ \\
\hline $90 \mathrm{~kg} \mathrm{ha}^{-1}$ de $\mathrm{N}$ & & $1,726.39$ & & $1,909.41$ \\
\hline $60 \mathrm{~kg} \mathrm{ha}^{-1}$ de $\mathrm{N}$ & & $1,658.47$ & & $1,834.12$ \\
\hline $30 \mathrm{~kg} \mathrm{ha}^{-1}$ de N & & $1,590.15$ & & $1,758.83$ \\
\hline $0 \mathrm{~kg} \mathrm{ha}^{-1}$ de $\mathrm{N}$ & & $1,521.84$ & & $1,638.55$ \\
\hline
\end{tabular}

*Low density polyethylene drip tapes $(14,300 \mathrm{~m})$, with emitters spaced $0.30 \mathrm{~m}$ and nominal diameter $16 \mathrm{~mm}($ service life $=2 \mathrm{years}$, value $\left.=\mathrm{R} \$ 0.24 \mathrm{~m}^{-1}\right)$; pipes and connections in PVC (life $=16$ years, value of the new good $\left.=\mathrm{R} \$ 2,986.50 \mathrm{ha}^{-1}\right)$.

**Total cost without value of the seeds $\left(4 \mathrm{~kg} \mathrm{ha}^{-1}\right)$.

The production costs per cultivar were variable in the agricultural crops, due to the seed prices added to the total cost of production. In 2016 the variation for 'Altis 99' cultivar was R\$ 1,561.24 $\mathrm{ha}^{-1}$ (absence of $\mathrm{N}$ fertilization + seeds $\mathrm{ha}^{-1}$ ) at $\mathrm{R} \$$ $1,836.75 \mathrm{ha}^{-1}\left(120 \mathrm{~kg} \mathrm{ha}^{-1}\right.$ of $\mathrm{N}+$ seeds ha $\left.{ }^{-1}\right)$; for 'Aguará 06': R\$ 1,569.24 ha ${ }^{-1}$ to $\mathrm{R} \$ 1,844.75 \mathrm{ha}^{-1}$; 'Multissol': R\$ $1,573.24 \mathrm{ha}^{-1}$ to R\$ $1,848.75 \mathrm{ha}^{-1}$; 'BRS 122', R\$ 1,553.24 $\mathrm{ha}^{-1}$ to R\$ $1,828.75 \mathrm{ha}^{-1}$ respectively. In 2017, for 'Altis 99' cultivar, it was R\$ $1,689.35 \mathrm{ha}^{-1}$ to $\mathrm{R} \$ 2,010.11 \mathrm{ha}^{-1}$; 'Aguará 06 ' from R\$ 1,694.55 ha ${ }^{-1}$ to $\mathrm{R} \$ 2,045.31 \mathrm{ha}^{-1}$; 'Multissol' from R\$ 1,706.95 ha ${ }^{-1}$ to $\mathrm{R} \$ 2,057.71 \mathrm{ha}^{-}$ ${ }^{1}$ and for 'BRS 122', the variation was R\$1,678.55 $\mathrm{ha}^{-1}$ to R\$2,029.31 ha $\mathrm{ha}^{-1}$. It is found that the seed input accounted, on average, for $3.61 \%$ of the operating cost of the holding. In the acquisition of seeds among the cultivars, the 'Multissol' cultivar was the one that most charged, with about $4.00 \%$.

Surveys obtained by Epamig (2015), with the total operational costs per hectare of sunflower production, in the 2014/2015 harvest, in the Triângulo Mineiro (MG), expenses reached $\mathrm{R} \$$ $840,00 \mathrm{ha}^{-1}$. While in Campo Novos do Parecis (MT), Tarsinato et al. (2016) reported expenditures of R $\$ 1,391.72 \mathrm{ha}^{-1}$. In these surveys, input costs $(\approx$ $50 \%$ ) were the factor that most affected sunflower cultivation, followed by mechanized operations $(33 \%)$ and manuals $(9.20 \%)$. 
Similar values were obtained for fertirrigated sunflower production in the Brazilian semi-arid region, where the factors that most burdened crop costs were labor costs in sowing, weeding, irrigation system management, harvesting, trail and cleaning of the achenes, with participation in $17.81 \%$ of the total costs in the 2016 harvest and $22.62 \%$ in 2017. Evaluation (KHATUN et al., 2016) of the costs of one hectare of sunflower found greater expenditure on labor, about $40 \%$ of the total cost.

The opportunity cost related to the rental of agricultural property per crop cycle in 2016 was R\$ $337.50 \mathrm{ha}^{-1}$, and in $2017 \mathrm{R} \$ 379.70 \mathrm{ha}^{-1}$ (Table 4). This expenditure was higher in the 2017 crop as a function of the sunflower production cycle has been prolonged.

The depreciation of improvements/facilities for crops of sunflower cultivars production in semiarid climates ( 85 to 95 DAS) was $0.5 \%$ between harvests (Table 4), due to the duration of the cycle in the agricultural harvest, and it is essential that the producer save the amounts corresponding, in order to replace the dripping tapes and other components of the irrigation system in the expected time of its useful life.

The low mechanization, associated to the non-use of herbicides, characteristic of Northeastern family agriculture, favored the operating margin presented between the growing seasons. The use of family labor in small and medium-sized properties during the production, harvesting and processing stages will dissolve the cost of sunflower production that taxe the production sunflower and reward for higher net family income.

In addition, the use of sunflower in crop rotation systems is already established practice, which reduces production costs and idleness of productive areas. The succession of crops in melon areas is a favorable practice, using residual fertilization of deeper layers and improving soil quality, considering that the production costs of one hectare of melon can be estimated at R $\$ 17,795.50$ $\mathrm{ha}^{-1}$ and the cultivation of sunflower in the offseason will allow to cover part of the operational costs (SANTOS et al., 2018).

From the difference between the gross income and the total costs of production, it has the net income from the production of sunflower. In the 2016 harvest, the net income increased until the dose of 81 and $118 \mathrm{~kg} \mathrm{ha}^{-1}$ of $\mathrm{N}$ for the cultivars 'BRS 122' (R\$ $366.89 \mathrm{ha}^{-1}$ ) and 'Multissol' (R\$ $577.41 \mathrm{ha}^{-1}$ ), respectively (Figure 3A). In the same year, there were maximum net incomes in the dose of $120 \mathrm{~kg} \mathrm{ha}^{-1}$ for 'Aguará 06' (R\$ 2,124.00 ha ${ }^{-1}$ ) and 'Altis 99' (R\$ $\left.976.66 \mathrm{ha}^{-1}\right)$. In the agricultural crops, non-fertirrigated cultivars with $\mathrm{N}$, had negative net income (Figures 3A and 3B), except for 'Altis 99' in the 2017 crop (Figure 3B), which had R\$ 184.50 ha $^{-}$ ${ }^{1}$ (absence of $\mathrm{N}$ fertilizer) to $\mathrm{R} \$ 957.14 \mathrm{ha}^{-1}$ in the dose of $120 \mathrm{~kg} \mathrm{~N} \mathrm{ha}^{-1}$. In the 2017 harvest, 'Aguará 06 ' reached income of $\mathrm{R} \$ 1,078.0 \mathrm{ha}^{-1}$ associated with the fertirrigation of $120 \mathrm{~kg} \mathrm{~N}^{-1}$, while 'BRS $122^{\prime}$ net income was $\mathrm{R} \$ 190.90 \mathrm{ha}^{-1}$ at the ideal dose of $83.5 \mathrm{~kg} \mathrm{ha}^{-1}$ of N and for Multisol, R\$ $657.50 \mathrm{ha}^{-1}$ with $85.20 \mathrm{~kg} \mathrm{~N} \mathrm{ha}^{-1}$ (Figures $3 \mathrm{~A}$ and 3B).
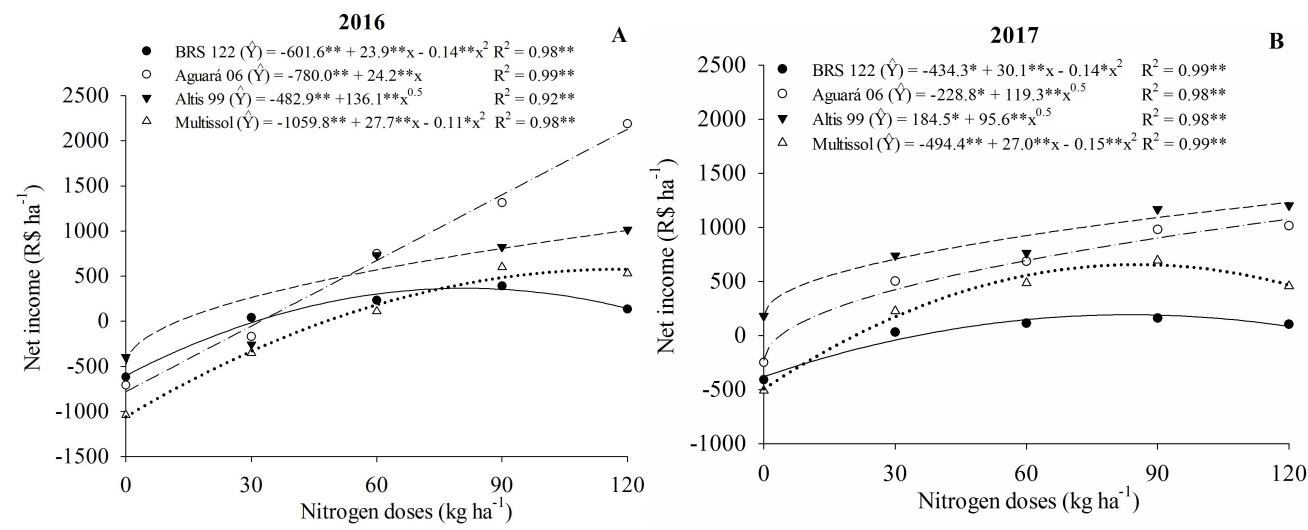

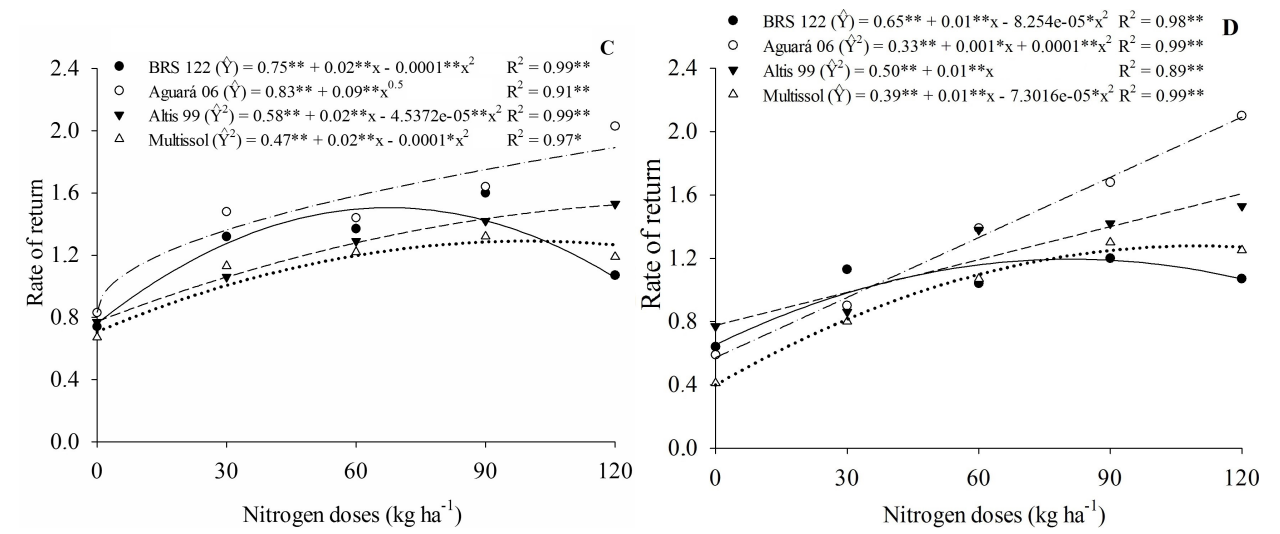

Figure 3. Net income (A, B) and rate of return (C, D) of sunflower cultivars fertirrigated with nitrogen doses in two agricultural crops in the Brazilian semi-arid region.

In relation to the rate of return on sunflower crop investment in the 2016 harvest, the estimated doses of 79 and $82 \mathrm{~kg} \mathrm{ha}^{-1}$ of $\mathrm{N}$ corresponded to the estimated value of R\$ 1.13 for 'BRS 122 ' and R\$ 1.29 for 'Multisol' per invested real (Figure 3C). The cultivars 'Aguará 06' and 'Altis 99' obtained a higher rate of return in the dose corresponding to $120 \mathrm{~kg}$ $\mathrm{ha}^{-1}$ of $\mathrm{N}$ in the two agricultural crops. In 2017, the highest rates of return were obtained with the doses of 81 and $109 \mathrm{~kg} \mathrm{ha}^{-1}$ of $\mathrm{N}$ for 'BRS 122' (1.19) and 'Multissol' (1.27) (Figure 3D). These data are in agreement with the results obtained by (FEITOSA et al., 2016; KANANNAVAR et al., 2013; UNAKITAN; AYDIN, 2018) whose rates of return were positive for sunflower production.

On the basis of the data, we verified the existence of a positive return in the fertirrigated conditions of sunflower cultivation, however, with a lower remuneration than other forms of capital application (opportunity cost). A form of cost reduction and net margin increase is the investment in the sunflower activity in the off-season, which will be advantageous for the producer, covering the variable costs of this crop and part of the fixed costs invested in the main activity, providing a contribution to the cycling of nutrients of the previous harvest and maintaining the soil covered, favoring the conservationist system of agricultural soil.

For the 2016 crop profitability index, the $\mathrm{N}$ dose and 81 and $94 \mathrm{~kg} \mathrm{ha}^{-1} \mathrm{~N}$ doses for 'BRS 122' and 'Multissol' cultivars yielded a maximum profitability index of $28.74 \%$ and $25.80 \%$, respectively (Figure 4A). For 'Aguará 06' and 'Altis 99' cultivars the best response was achieved with the dose of $120 \mathrm{~kg} \mathrm{ha}^{-1}$ of $\mathrm{N}$ in the two agricultural crops (Figures 4A and 4B). Similarly, in 2017, fertirrigation doses of 93 and $81 \mathrm{~kg} \mathrm{ha}^{-1}$ of $\mathrm{N}$ corresponded to the highest profitability indices for 'BRS 122' (37.81\%) and 'Multissol' (24.78\%) cultivars, respectively (Figure 4B). These results were higher than the profitability index obtained by Tarsinato et al. (2016) in the production of sunflower in Mato Grosso, whose profitability index was $12.85 \%$.
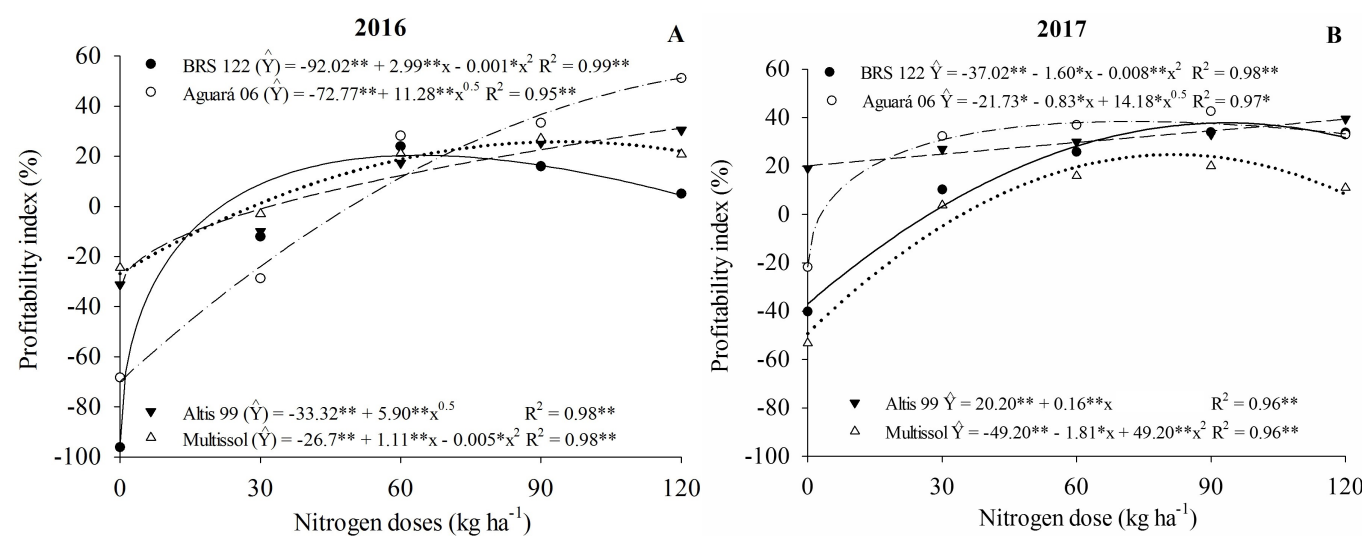

Figure 4. Profitability index (A, B) of sunflower cultivars fertirrigated with nitrogen doses in two agricultural crops in the Brazilian semi-arid. 
It is worth mentioning that, in addition to the technical and economic feasibility of the production of achenes obtained in this study, the cultivation of the sunflower makes it possible to increase income in family farms in this Brazilian geographic region, making possible the production of honey (SIMIONI et al., 2015), viabilizing of animal production, in the partial replacement of protein supplementation of soybeans for sunflower meal (JUNQUEIRA et al., 2010; OLIVEIRA et al., 2016), as well as being used as crop in rotation and succession in melon and other crop production areas, recycling nutrients from deeper layers of soil, improving soil quality, reducing the idleness of agricultural areas between crops and increasing per capita income of farmers.

\section{CONCLUSIONS}

The net margin corresponded to the increase of $\mathrm{N}$ doses, reaching maximum values in 2016 of $\mathrm{R} \$$
$366.89 \mathrm{ha}^{-1}$ at the dose of $81 \mathrm{~kg} \mathrm{ha}^{-1}$ of $\mathrm{N}$ for 'BRS 122'; for 'Multissol' of R\$ $577.41 \mathrm{ha}^{-1}$ with $118 \mathrm{~kg}$ $\mathrm{ha}^{-1}$ of N. The 'Aguará 06' reached R \$2,124.00 ha and 'Altis 99', R $\$ 976.66 \mathrm{ha}^{-1}$ in the dose of $120 \mathrm{~kg}$ $\mathrm{ha}^{-1}$ of $\mathrm{N}$.

In the 2017 harvest, 'BRS 122' received R\$ $190.90 \mathrm{ha}^{-1}$ in the dose of $83.0 \mathrm{~kg} \mathrm{ha}^{-1}$ of $\mathrm{N}$ and 'Multissol' reached R\$ 657.50 in the dose of $85.0 \mathrm{~kg}$ $\mathrm{ha}^{-1}$ of $\mathrm{N}$; the cultivars 'Aguará 06' (R\$1,078.00 ha' $\left.{ }^{1}\right)$ and 'Altis 99' (R\$957.14 ha $\left.{ }^{-1}\right)$, in turn, at the dose of $120 \mathrm{~kg} \mathrm{ha}^{-1}$ of $\mathrm{N}$.

\section{ACKNOWLEDGMENTS}

This study was financed in part by the Coordenação de Aperfeiçoamento de Pessoal de Nível Superior - Brasil (CAPES) - Finance Code 001.

To the Federal Rural Semi-Arid University (UFERSA) and to the Postgraduate Program in Plant Science (PPGF).

RESUMO: O girassol é uma das mais importantes oleaginosas do mundo. No entanto, o cultivo em regiões semiáridas requer análise dos custos de produção e rentabilidade, garantindo tomadas de decisão eficazes, focadas em procedimentos e técnicas agrícolas. Em duas safras agrícolas, 2016 e 2017, foram conduzidos experimentos para avaliar os indicadores econômicos de cultivares de girassol ('Aguará 06', 'Altis 99', 'Multissol' e 'BRS 122') submetidos a doses de nitrogênio (N) $\left(0 ; 30 ; 60 ; 90\right.$ e $\left.120 \mathrm{~kg} \mathrm{ha}^{-1}\right)$ via fertirrigação em condições semiáridas. A margem líquida correspondeu ao aumento das doses de $\mathrm{N}$, atingindo uma margem líquida máxima na safra 2016 de R $\$ 366,89 \mathrm{ha}^{-1}$ na dose de $81 \mathrm{~kg} \mathrm{ha}^{-1}$ de N para 'BRS 122'; R\$ 577,41 ha com $^{-1}$ $118 \mathrm{~kg} \mathrm{ha}^{-1}$ de N para 'Multissol'; e para 'Aguará 06' (R\$2.124,00 ha-1) e 'Altis 99' (R\$ 976,66 ha $\left.{ }^{-1}\right)$ na dose de $120 \mathrm{~kg} \mathrm{ha}^{-1}$ de N. Na safra de 2017, 'BRS 122' obteve R\$ 190,90 ha ${ }^{-1}$ na dose de $83 \mathrm{~kg} \mathrm{ha}^{-1}$ de N e 'Multissol' alcançaram R \$ 657,50 na dose de $85 \mathrm{~kg} \mathrm{ha}^{-1}$ de N; as cultivares 'Aguará 06' (R\$1.078,00 ha ${ }^{-1}$ ) e 'Altis 99' (R\$ $957,14 \mathrm{ha}^{-1}$ ) na dose de $120 \mathrm{~kg} \mathrm{ha}^{-1} \mathrm{de} \mathrm{N}$. A taxa de retorno e o índice de lucratividade foram positivos para todas as cultivares em ambas as culturas.

PALAVRAS-CHAVE: Custo de produção. Helianthus annuus. Produtividade. Época de plantio.

\section{REFERENCES}

ARSHAD, M. N.; AHMAD, A.; WAJID, A.; RASUL, F.; KHALIQ, T.; AWAIS, M.; FATIMA, H. N. Quantification of growth, yield and radiation use efficiency of sunflower at different irrigation and nitrogen levels under semi-arid conditions of Faisalabad. Journal of Agricultural Research, Lahore, v. 54, n. 4, p. 647656, 2016.

BANERJEE, H.; DUTTA, S. K.; PRAMANIK, S. J.; RAY, K.; PHONGLOSA, A.; BHATTACHARYYA, K. Productivity and profitability of spring planted sunflower hybrid with nitrogen, phosphorus and potassium fertilizer. Annals of Plant and Soil Research, India, v. 16, n. 2, p. 250-256, 2014.

CAPONE, A.; SANTOS, E. R. dos; FERRAZ, E. C.; SANTOS, A. F. dos; OLIVEIRA, J. L. de; BARROS, H. B. Desempenho agronômico de cultivares de girassol no sul do Estado Tocantins. Journal of Biotechnology and Biodiversity, Gurupi, v. 3, n. 3, p. 1-4, 2012. https://doi.org/10.20873/jbb.uft.cemaf.v3n3.capone 
CASTRO, C.; LEITE, R. M. V. B. C. Main aspects of sunflower production in Brazil. Oilseeds and fats, Crops and Lipids, Les Ulis, v. 25, n. 1, p. 104-115, 2018. https://doi.org/10.1051/ocl/2017056

CONAB - Companhia Nacional de Abastecimento. Custos de produção agrícola: a metodologia da Conab. Brasília: CONAB, 2010. 60 p.

CUNHA, J. L. de O.; PORDEUS, R. V.; SILVA JÚNIOR, M. J. da; PONTES, F. S. T.; AZEVEDO, C. A. V. de. Impactos econômicos da depreciação de sistemas de irrigação por gotejamento nos custos de produção agrícola. Enciclopédia Biosfera, Goiânia, v. 8, n. 15, p. 1008-1020, 2012.

EMBRAPA - Empresa Brasileira de Pesquisa Agropecuária. Sistema brasileiro de classificação de solos. 3. Ed. Brasília: Embrapa, 2013. 352 p.

EPAMIG - Empresa de Pesquisa Agropecuária de Minas Gerais. Custo de produção do girassol no estado de Minas Gerais: Safra 2014/15. 2015.

FAO - Food and Agriculture Organization of the United Nations. Faostat: production crops (sunflower), 2018. Disponível em: <https://www.fao.org/faostat/en/\#data/QC>. Acesso em: 22 jan. 2018.

FERREIRA, D. F. Sisvar: a computer statistical analysis system. Ciência e Agrotecnologia, Lavras, 2011; v. 35, n. 6, p. 1039-1042. https://doi.org/10.1590/S1413-70542011000600001

GUEDES FILHO, D. H.; CHAVES, L. H.; CAMPOS, V. B.; SANTOS JÚNIOR, J. A.; OLIVEIRA, J. T. de. Production of sunflower and biomass depending on available soil water and nitrogen levels. Iranian Journal of Energy and Environment, Babol, v. 2, n. 4, p. 313-319, 2011.

https://doi.org/10.5829/idosi.ijee.2011.02.04.1789

FEITOSA, H. de O.; LACERDA, C. F. de; MARINHO, A. B.; COSTA, R. N.; CARVALHO C. M. de; GHEYI, H. R. Productivity and economic analysis of sunflower/maize crop rotation under different levels of salinity and nitrogen. African Journal of Agricultural Research, Ago-Iwoye, v. 11, n. 23, p. 1999-2006, 2016. https://doi.org/10.5897/AJAR2016.10955

JANDEL SCIENTIFIC. Table Curve 2D: curve fitting software. Corte Madera: Jandel Scientific; 1992, 280 p.

JUNQUEIRA, O. M.; FILARDI, R. da S.; LIGEIRO, E. C.; CASARTELLI, E. M.; SGAVIOLI, S.; ASSUENA, V.; DUARTE, K. F.; LAURENTIZ, A. C. de. Avaliação técnica e econômica da matriz nutricional da enzima fitase em rações contendo farelo de girassol para poedeiras comerciais. Revista Brasileira de Zootecnia, Viçosa, v. 39 n. 10, p. 2200-2206, 2010. https://doi.org/10.1590/S1516-35982010001000015

KANANNAVAR, P. S.; RUDRAGOUDA, C.; VASANTHGOUDA, B. R.; RAVINDRA, Y.; NAGARAJ, D. M. The economic analysis of sunflower production. International Journal of Agricultural Engineering, Kumarganj, v. 6, n. 1, p. 227-230, 2013.

KANTER, D. R.; ZHANG, X.; MAUZERALL, D. L. Reducing nitrogen pollution while decreasing farmers' costs and increasing fertilizer industry profits. Journal of Environmental Quality, Madison, v. 44, n. 2, p. 325-335, 2015. https://doi.org/10.2134/jeq2014.04.0173

KHAKWANI, A. A.; NOOR, S.; SADIQ, M.; AWAN, I. U.; MUNIR, M.; GHAZANFARULLAH, M. S. B.; BAKHSH, I. Impact of plant densities and NPK fertilization on growth and optimum economic return of sunflower. Sarhad Journal of Agriculture, Peshawar, v. 30, n. 2, p. 157-164, 2014.

KHATUN, M.; HOSSAIN, T. M.; MIAH, M. A. M.; KHANDOKER, S.; RASHID, M. A. Profitability of sunflower cultivation in some selected sites of Bangladesh. Bangladesh Journal of Agricultural Research, Gazipur, v. 41, n. 4, p. 599-623, 2016. https://doi.org/10.3329/bjar.v41i4.30694 
KIANI, M.; GHEYSARI, M.; MOSTAFAZADEH-FARD, B.; MAJIDI, M. M.; KARCHANI, K.; HOOGENBOOM, G. Effect of the interaction of water and nitrogen on sunflower under drip irrigation in an arid region. Agricultural Water Management, Auckland, v. 171, n. 1, p. 162-172, 2016. https://doi.org/10.1016/j.agwat.2016.04.008

MATSON, P. A.; NAYLOR, R.; ORTIZ-MONASTERIO, I. Integration of environmental, agronomic, and economic aspects of fertilizer management. Science, Washington, v. 280, n. 5360, p. 112-115, 1998. https://doi.org/10.1126/science.280.5360.112

OLIVEIRA, V. R. de M.; ARRUDA, A. M. de; SILVA, L. N.; SOUZA JÚNIOR, J. B. F. de; QUEIROZ, J. P. A. F. de; MELO, A. da S.; HOLANDA, J. S. Sunflower meal as a nutritional and economically viable substitute for soybean meal in diets for free-range laying hens. Animal Feed Science and Technology, Thessaloniki, v. 220 n. 1, p.103-108, 2016. https://doi.org/10.1016/j.anifeedsci.2016.07.015

PERSON, L. C. Ótima opção para o agronegócio brasileiro. AgroAnalysis, São Paulo, v. 33, n. 02, p. 27-28, 2016.

PIMENTEL GOMES, F. Curso de estatística experimental. 15 ed. Piracicaba: FEALQ, 2009. 451 p.

RIBEIRO, A. C.; GUIMARÃES, P. T. G.; VENEGAS, V. H. A. (Ed.). Recomendações para o uso de corretivos e fertilizantes em Minas Gerais. $5^{\text {a }}$ aproximação. Viçosa: Comissão de Fertilidade do Solo do Estado de Minas Gerais, 1999. 359 p.

SANTOS, A. C. dos; ANDRADE, A. P. de; LIMA J. R. de S.; SILVA, I. F. da; CAVALCANTE, R. V. Variabilidade temporal da precipitação pluvial: nível de nitrogênio no solo e produtividade de cultivares de girassol. Ciência Rural. Santa Maria, v. 32, n. 5, p. 757-764, 2002. https://doi.org/10.1590/S010384782002000500004

SANTOS, T. de L.; NUNES, A. B. A.; GIONGO, V.; BARROS, V. da S.; FIGUEIRÊDO, M. C. B. de. Cleaner fruit production with green manure: The case of Brazilian melons. Journal of Cleaner Production, Brno, v. 181, n. 1, p. 260-270, 2018. https://doi.org/10.1016/j.jclepro.2017.12.266

SCHULTZ, E.; DESUTTER, T.; SHARMA, L.; ENDRES, G.; ASHLEY, R.; BU, H.; MARKELL, S.; KRAKLAU, A.; FRANZEN, D. Response of sunflower to nitrogen and phosphorus in North Dakota. Agronomy Journal, Madison, v. 110, n. 2, p. 685-695, 2018. https://doi.org/10.2134/agronj2017.04.0222

SCHWERZ, F.; CARON, B. O.; ELLI, E. F.; OLIVEIRA, D. M. de; MONTEIRO, G. C.; SOUZA, V. Q. de. Avaliação do efeito de doses e fontes de nitrogênio sobre variáveis morfológicas, interceptação de radiação e produtividade do girassol. Ceres, Viçosa, v. 63, n. 3, p. 380-386, 2016. https://doi.org/10.1590/0034737X201663030015

SILVA, F. C. da. Manual de análises químicas de solos, plantas e fertilizantes. 2. ed. Brasília: Embrapa Informação Tecnológica, 2009. 627 p.

SIMIONI, L. C.; MUSSURY, R. M.; MAUAD, M.; DRESH. D. M.; PEREIRA, F. F.; SCALON, S. P. Plantpollinator interactions in Crambe abyssinica Hochst. (Brassicaceae) associated with environmental variables. Anais da Academia Brasileira de Ciências, Rio de Janeiro, v. 87, n. 1, p. 137-145, 2015. https://doi.org/10.1590/0001-3765201520130365

SIMÕES, W. L.; DRUMOND, M. A.; OLIVEIRA, A. R. de; GONCALVES, S. L.; GUIMARÃES, M. J. M. Morphophysiological and productive responses of sunflower varieties to irrigation. Revista Caatinga, Mossoró, v. 31, n. 1, p. 143-150, 2018. https://doi.org/10.1590/1983-21252018v31n117rc 
SINCIK, M.; GOKSOY, A. T.; DOGAN, R. Responses of sunflower (Helianthus annuus L.) to irrigation and nitrogen fertilization rates. Zemdirbyste-Agriculture, Lithuania, v. 100, n. 2, p. 151-158, 2013. https://doi.org/10.13080/z-a.2013.100.019

SOBRINHO, J. E.; PEREIRA, V. C.; OLIVEIRA, A. D.; SANTOS, W. O.; SILVA, N. K.; MANIÇOBA, R. M. Climatologia da precipitação no município de Mossoró - RN. Período: 1900-2010. In: CONGRESSO BRASILEIRO DE AGROMETEOROLOGIA, XVII, Guarapari. Anais... Guarapari: SESC Centro de Turismo de Guarapari, 2011. p. 1-4.

TARSINATO, R. A.; LAFORGA, G.; PROENÇA, É. R.; RAPASSI, R. M. Custos e rentabilidade da produção de girassol no estado do Mato Grosso, Brasil. Revista Espacios, Caracas, v. 37, n. 12, p. 26-35, 2016.

TAVARES, S. R. de L. Manual de construção e utilização de sistema simplificado de injeção de fertilizantes via água de irrigação destinado à agricultura familiar. Rio de Janeiro: Embrapa Solos, 2015, 26 p. (Documentos, 191).

UNAKITAN, G.; AYDIN, B. A comparison of energy use efficiency and economic analysis of wheat and sunflower production in Turkey: A case study in Thrace Region. Energy, Aalborg, v. 149, n. 2, p. 279-285, 2018. https://doi.org/10.1016/j.energy.2018.02.033

USDA - United States Department of Agriculture. World Agricultural Production, 2018. Disponível em: $<$ https://apps.fas.usda.gov/psdonline/circulars/production.pdf $>$. Acesso em: 26 jan. 2018.

WABEKWA, J. W.; DEGRI, M. M.; DANGARI, L. C. The effects of nitrogen mineral on yield performance of sunflower (Helianthus annuus L.) in Bauchi State, Nigeria. Journal of Environment Issues in Agricultural Developing Countries, Nigeria, v. 4, n. 3, p. 56-61, 2012. 